\title{
Sudangrass productivity when cultivating for fodder in the conditions of the Cis-Ural steppe of the Bashkortostan Republic
}

\author{
R.A. Biktimirov*, A.A. Nizaeva, A.H. Shakirzyanov, and Z.M. Sharipkulova \\ Ufa Federal Research Center of the Russian Academy of Sciences, Bashkir Research Institute of \\ Agriculture, Ufa, Russia
}

\begin{abstract}
Producing high-quality fodder is one of the most urgent priorities in agriculture of the Bashkortostan Republic. The Sudangrass cultivation can address the issue of getting high-quality animal feed in the region. The given paper presents the results of experimental studies on improving the Sudangrass growing technology in the conditions of the Bashkortostan's Cis-Ural steppe, based on the best possible and scientifically proven sowing time, methods and seeding rates. Previous studies have established the way these factors affect the productivity of Sudangrass variety Demskaia. It was found that the Sudangrass variety Demskaia requires a seeding rate of 2.5-3.0 million fertile seeds per 1 ha to realize the productivity potential. The best time for sowing Sudangrass is late May when the soil steadily warms up to $+14^{\circ}-+18^{\circ} \mathrm{C}$. The highest crude protein content was observed at earlier sowing with the seeding rate of 2.5-3.0 million fertile seeds per hectare. The higher seeding rate results in the increased leaf area and photosynthetic potential but cuts the net productivity of photosynthesis. The leaf surface area reaches its peak in the "full emergence" phase in the trial with a $15-\mathrm{cm}$ row-width spacing at the seeding rate of 2.5-3.0 million fertile seeds per hectare.
\end{abstract}

\section{Introduction}

Sudangrass plays an essential part in solving the problem of producing high-quality fodder. This highly productive crop is distinguished by its nutritional value, multipurpose use and the ability for quick aftergrowth after mowing. Due to its biological characteristics, Sudangrass can withstand droughts and effectively use precipitation in the second half of the growing season. All these characteristics make Sudangrass a vital crop that meets the requirements of intensive feed production $[1,2]$.

In recent years, new highly productive and promising Sudangrass varieties have been developed; therefore, studies aimed at improving the basic cultivation practices for the given crop in the conditions of the Cis-Uralian Bashkir steppe are relevant and timely [7, 8].

*Corresponding author: sci_secr_bniish@bk.ru 


\section{Materials and Methods}

The effect of cultivation technology on the Sudangrass productivity was studied in the Ufa Federal Research Center's Bashkir Agricultural Research Institute of the Russian Science Academy in the conditions of the Cis-Ural steppe zone in 2017-2019.

The soil of the experimental plot is medium-loamy medium-deep typical chernozem. The average humus content in the upper arable layer ranges from 7 to $9 \%$ (according to Tiurin). The reaction of the soil solution is close to neutral, being 7.1...7.4. The content of total nitrogen is $0.4 \%$ (Kjeldahl), $20.5 \mathrm{mg}$ exchangeable potassium (by Chirikov), $10.2 \mathrm{mg}$ labile phosphorus (by Chirikov), $35 \mathrm{mg}$-EQ calcium (by Aidinian) per $100 \mathrm{~g}$ of dry soil.

Field experiments to study the impact of sowing time and methods, seeding rates on the productivity of forage weight and seed productivity were conducted on a new promising Sudangrass variety Demskaia. The cultivar was developed by multiple family-group and individual selection. The plants with the highest productivity and intensive initial growth were selected from a hybrid population obtained by intervariety hybridization of Kinelskoe 3 sugar sorghum and early Sudangrass variety Chishminskaia.

The variety is middle-early with a 33-41 day period from full seed germination to the first mowing and 78 days from full sprouts to full seed ripeness. The variety is characterized by an intense growth in the initial period getting $79.4 \mathrm{~cm}$ for the first 30 days of vegetation (from germination to full ear emergence); it grows well after mowing.

Plants are $217 \mathrm{~cm}$, medium-bushy, thin-stemmed, 6-7- leafed. The leaf is broadly linear, lanceolate, up to $47 \mathrm{~cm}$ long, up to $2.8 \mathrm{~cm}$ wide. It is quite resistant to red bacterial spotting. The glume is black, $10-15 \%$ cherry-red. The fruiting spikelets are double-edge, the awns are cranked-curved. The grain is ellipsoid, light brown and straw-yellow. The weight of 1000 seeds is $15.0 \mathrm{~g}$.

Field experiments were undertaken based on the methodology of the State crop variety testing [12]. Spring wheat served as a precursor in the experiment. Sowing was carried out in the following terms: 1st term-May 8, 2nd term-May 17, 3rd term-May 27 and 4th termJune 5 (depending on weather conditions during sowing), a seeding rate of 1.5; 2.0, 2.5 and $3.0 \mathrm{mln}$ fertile seeds per $1 \mathrm{ha}$, a row-width spacing of 15,30 and $45 \mathrm{~cm}$, with an SN-16 seeder. The experiment is two-factor. The total area of the experimental plot was $18.9 \mathrm{~m}^{2}$, the accounting area for green mass was $5 \mathrm{~m}^{2}$, for seeds $-10 \mathrm{~m}^{2}$. Treatments were placed systematically in a four-fold repetition. All records and related observations were carried out under the All-Russian Scientific Research Institute of Feed methodology named after V. R. Williams [3] and the methodology of field experience [5].

The nutritional value of the Sudangrass green mass was determined in the laboratory according to generally accepted methods.

In 2017 , the third decade of May was rainy $\left(213 \%\right.$ of the norm) and cool $\left(12.1^{\circ} \mathrm{C}\right)$. The first decade of June can be characterized as cool $\left(11.8^{\circ} \mathrm{C}\right)$, the second as moderately warm $\left(17.3^{\circ} \mathrm{C}\right)$, the third was also not very warm $\left(17.2^{\circ} \mathrm{C}\right)$, precipitation in June in the decades was $447 ; 96$ and $115 \%$ of the norm. In July, the average air temperature was 17.2, 19.3 and $21.1^{\circ} \mathrm{C}$, and precipitation 30.6, 15.9 and $1.2 \mathrm{~mm}$ by decades. In August, the average air temperature was $20.2 ; 17.2$; and $19.6^{\circ} \mathrm{C}$ for decades, and precipitation was $24.1 ; 4.8$ and 9.1 $\mathrm{mm}$, respectively.

The end of May 2018 was rainy (154\% of the average annual values) and warm $\left(14.7^{\circ} \mathrm{C}\right)$. The first two decades of June were cool $\left(12.4\right.$ and $15.6^{\circ} \mathrm{C}$, which is 4.4 and $2.1^{\circ} \mathrm{C}$ below the average annual data), the third decade was warm $\left(21.1^{\circ} \mathrm{C}\right)$, precipitation for the decades was $16.6 ; 6.5$ and $35 \%$ of the norm. In July, the air temperature was $22.4,21.2$ and $20.6^{\circ} \mathrm{C}$ for decades, which is higher than the long term average annual values by $3.1,1.8$ and $1.9^{\circ} \mathrm{C}$, precipitation was $6.7,12.8$ and $0.0 \mathrm{~mm}$, respectively. In August, the air 
temperature for decades was at the standard level $-20.3 ; 17.9$; and $16.2^{\circ} \mathrm{C}$, precipitation was $83 ; 53$ and $79 \%$ of the average long term annual values.

The third decade of May 2019 was quite warm $-14.6^{\circ} \mathrm{C}$ and $24.1 \mathrm{~mm}$ wet. In June, the average air temperature for decades was: $16.5,16.4$, and $19.4^{\circ} \mathrm{C}$ or $-0.3 ;-1.3$ and $+1.3^{\circ} \mathrm{C}$ from the norm. The first decade was rainy, $183.3 ; 22.1$ and $32.0 \%$ of the average annual precipitation values. In July, the first decade was cool at $17.9^{\circ} \mathrm{C}\left(-1.4^{\circ} \mathrm{C}\right)$; the second one was warm $\left(+1.8^{\circ} \mathrm{C}\right)$, and the third decade was within the norm; precipitation for decades was for decades 148.3; 40 and 13\% of the norm. The first decade of August was cold, the second-warm, the third - cool $\left(-3,3 ;+1,4\right.$ and $-1,7^{\circ} \mathrm{C}$ of the norm), precipitation for the decades was 298,$7 ; 114$ and $66 \%$ of the norm. In the first decade of September, the air temperature was below the norm by $2.0^{\circ} \mathrm{C}$; the second decade was within the norm $\left(+0.7^{\circ} \mathrm{C}\right)$; precipitation for decades was $26.8 ; 167 \%$ of the norm.

Statistical processing of the findings was performed by the variance analysis method using Microsoft Excel.

\section{Results and Discussion}

The length of the growing season is specific for each Sudangrass variety but varies significantly depending on external conditions. As a heat-loving crop, Sudangrass has a rather limited distribution area and the main factor that affects its distribution, growth, development, and yield in our conditions is the warm weather. In general, the Sudangrass growth and development is determined by a complex of factors that mutually affect each other [4].

The most noticeable influence on the interphase period was sowing time, with the soil hydrothermal conditions being the determining factor during sowing. Good soil moisture at a depth of seed embedding and optimal temperature contributed to even germination, while lack of moisture and low temperatures during the sowing period delayed seed germination.

The best sowing period for the experimental plot is the third decade of May and the beginning of the first decade of June when the soil has not lost moisture and warmed up to $+14-+16^{\circ} \mathrm{C}$. The findings indicated a change in the growing season duration for all the studied Sudangrass sowing time terms. Thus, it fluctuated within 80-94 and 76-92 days for the first and second sowing terms, and 71-94 and 72-94 days for the third and fourth terms (Table 1).

Increased seeding rate from 1.5 to $3.0 \mathrm{mln}$ fertile seeds per 1 hectare leads to the shorter height of plants in treatments. The earlier sown trials had significantly lower plant height compared with the later planted crops. On the contrary, the second mowing of early sown crops was higher. The first mowing was negatively affected by the sowing time, temperature conditions and vice versa; during the second mowing growth, hydrothermal conditions were favourable. When harvesting Sudangrass for seeds, the crop height of the last three sowing periods was higher than that of the first term, indicating that early sown plants grow under stress conditions.

Table 1. The main morphobiological characteristics of Sudangrass during sowing with different terms and seeding rates, on average for 2017-2019.

\begin{tabular}{|c|c|c|c|c|c|}
\hline $\begin{array}{c}\text { Sowing } \\
\text { time }\end{array}$ & $\begin{array}{c}\text { Seeding } \\
\text { rates, } \\
\text { million } \\
\text { pcs/ha }\end{array}$ & \multirow{2}{*}{$\begin{array}{c}\text { The period "full } \\
\text { sprouts - full } \\
\text { ripeness", days }\end{array}$} & \multicolumn{3}{|c|}{$\begin{array}{c}\text { Length of the stand, } \\
\text { cm }\end{array}$} \\
\cline { 4 - 6 } & & $\begin{array}{c}\text { The first } \\
\text { mowing }\end{array}$ & $\begin{array}{c}\text { The } \\
\text { second } \\
\text { mowing }\end{array}$ & Harvesting \\
\hline 1 & 1.5 & 93 & 118 & 105 & 209 \\
\hline
\end{tabular}




\begin{tabular}{|c|c|c|c|c|c|}
\hline 2 & 1.5 & 90 & 122 & 99 & 214 \\
\hline 3 & 1.5 & 89 & 119 & 95 & 220 \\
\hline 4 & 1.5 & 87 & 110 & 88 & 210 \\
\hline 1 & 2.0 & 92 & 118 & 104 & 199 \\
\hline 2 & 2.0 & 89 & 121 & 100 & 210 \\
\hline 3 & 2.0 & 87 & 124 & 98 & 207 \\
\hline 4 & 2.0 & 86 & 121 & 83 & 204 \\
\hline 1 & 2.5 & 92 & 115 & 110 & 194 \\
\hline 2 & 2.5 & 87 & 122 & 86 & 209 \\
\hline 3 & 2.5 & 88 & 123 & 86 & 204 \\
\hline 4 & 2.5 & 86 & 120 & 82 & 202 \\
\hline 1 & 3.0 & 91 & 118 & 109 & 194 \\
\hline 2 & 3.0 & 86 & 120 & 104 & 205 \\
\hline 3 & 3.0 & 86 & 120 & 86 & 200 \\
\hline 4 & 3.0 & 85 & 118 & 81 & 199 \\
\hline
\end{tabular}

The conducted studies explored the impact of the sowing time and methods, seeding rates on the Sudangrass yield. The following indicators characterized the productivity of the studied Sudangrass samples: the yield of green mass, absolutely dry matter and seeds at $15 \%$ humidity (Table 2). According to the average data, the highest yield of Sudangrass green mass, absolutely dry matter and seeds in the conditions of the Cis-Ural steppe zone were obtained at the third and fourth sowing periods. Their seeding rate was higher than the first and second sowing periods by $2.8-1.6 \mathrm{t} / \mathrm{ha}$. On average, over the years of research, the yield of absolutely dry matter in the experimental samples was 6.39-7.22 $\mathrm{t} / \mathrm{ha}$. The third and fourth sowing terms provided the highest yields of dry matter. The trial with a seeding rate of 2.5-3.0 mln fertile seeds per 1 ha revealed the highest yield of green mass and absolutely dry matter.

The sowing time affects seed productivity. The third and fourth trials had much higher seed productivity compared to treatments at earlier sowing. Thus, sowing on May 8 (the first sowing period) with a seeding rate of 3.0 million seeds/ha produced a yield of 2.61 t/ha. Later sowing on May 27 and June 5 provided 2.85-2.83 t/ha (respectively, the third and fourth sowing periods).

Table 2. The impact of sowing time and seeding rates on the Sudangrass yield, on average for 2017-2019.

\begin{tabular}{|c|c|c|c|c|}
\hline $\begin{array}{c}\text { Seeding rates, } \\
\text { million } \\
\text { seeds/ha }\end{array}$ & \multirow{2}{*}{$\begin{array}{c}\text { Sowing } \\
\text { time }\end{array}$} & \multicolumn{3}{|c|}{ Yield, t/ha } \\
\cline { 3 - 5 } & green mass & $\begin{array}{c}\text { absolutely- } \\
\text { dry } \\
\text { matter }\end{array}$ & $\begin{array}{c}\text { seeds at 15\% } \\
\text { humidity }\end{array}$ \\
\hline 1.5 & 1 & 29.3 & 6.39 & 2.46 \\
\hline 1.5 & 2 & 30.2 & 6.42 & 2.37 \\
\hline 1.5 & 3 & 32.4 & 6.72 & 2.64 \\
\hline 1.5 & 4 & 32.7 & 6.75 & 2.49 \\
\hline 2.0 & 1 & 30.6 & 6.61 & 2.29 \\
\hline 2.0 & 2 & 31.2 & 6.68 & 2.31 \\
\hline
\end{tabular}




\begin{tabular}{|l|l|l|l|l|}
\hline 2.0 & 3 & 33.1 & 6.98 & 2.61 \\
\hline 2.0 & 4 & 33.9 & 7.07 & 2.80 \\
\hline 2.5 & 1 & 31.8 & 6.63 & 2.63 \\
\hline 2.5 & 2 & 32.8 & 6.73 & 2.62 \\
\hline 2.5 & 3 & 35.1 & 7.18 & 2.73 \\
\hline 2.5 & 4 & 33.7 & 6.80 & 2.64 \\
\hline 3.0 & 1 & 31.9 & 6.85 & 2.61 \\
\hline 3.0 & 2 & 33.9 & 7.10 & 2.64 \\
\hline 3.0 & 3 & 35.8 & 7.22 & 2.85 \\
\hline 3.0 & 4 & 33.1 & 7.01 & 2.83 \\
\hline $\begin{array}{l}\text { LSD } 05 \text { for the seeding } \\
\text { rate, } \mathrm{t} / \mathrm{ha}\end{array}$ & 2.21 & 0.39 & 0.10 \\
\hline $\begin{array}{l}\text { LSD } 05 \text { for the sowing } \\
\text { time, } \mathrm{t} / \mathrm{ha}\end{array}$ & 3.42 & 0.45 & 0.14 \\
\hline
\end{tabular}

It was found that the best conditions to develop Sudangrass fodder and seed productivity were when sowing in the standard way $(15 \mathrm{~cm}$ row-width spacing) with a seeding rate of 2.5-3.0 mln fertile seeds per 1 hectare (Table 3 ).

Thickening from 1.5 to $3.0 \mathrm{mln}$ fertile seeds per 1 ha contributed to a significant increase in the productivity of both green mass and seeds in all trials with row spacing width. The conducted study revealed that the best seeding rate of Sudangrass in the conditions of the Cis-Ural steppe zone of the Republic of Bashkortostan is $3.0 \mathrm{mln}$ fertile seeds per 1 ha.

With increased row-width spacing up to $45 \mathrm{~cm}$, the yield significantly dropped.

Table 3. The effect of sowing methods and norms on the Sudangrass productivity when sown on May 27, for 2017-2019.

\begin{tabular}{|c|c|c|c|c|}
\hline \multirow{2}{*}{$\begin{array}{c}\text { Row-width } \\
\text { spacing, cm }\end{array}$} & $\begin{array}{c}\text { Seeding rate, } \\
\text { mln fertile } \\
\text { seeds per 1 ha }\end{array}$ & $\begin{array}{c}\text { green } \\
\text { mass }\end{array}$ & $\begin{array}{c}\text { absolutely dry } \\
\text { matter }\end{array}$ & $\begin{array}{c}\text { seeds at } 15 \% \\
\text { humidity }\end{array}$ \\
\cline { 3 - 5 } & 1.5 & 32.4 & 6.72 & 2.64 \\
\cline { 2 - 5 } & 2.0 & 33.1 & 6.98 & 2.61 \\
\cline { 2 - 5 } & 2.5 & 35.1 & 7.18 & 2.73 \\
\cline { 2 - 5 } & 3.0 & 35.8 & 7.20 & 2.85 \\
\hline \multirow{3}{*}{30} & 1.5 & 31.1 & 6.49 & 1.83 \\
\cline { 2 - 5 } & 2.0 & 32.7 & 6.82 & 1.97 \\
\cline { 2 - 5 } & 2.5 & 32.9 & 6.85 & 2.25 \\
\cline { 2 - 5 } & 3.0 & 33.5 & 6.96 & 2.54 \\
\cline { 2 - 5 } & 1.5 & 30.1 & 6.30 & 1.70 \\
\cline { 2 - 5 } & 2.0 & 31.6 & 6.57 & 2.93 \\
\cline { 2 - 5 } & 2.5 & 32.9 & 6.85 & 2.13 \\
\hline \multirow{3}{*}{45} & 3.0 & 32.3 & 6.77 & 0.18 \\
\hline LSD 05 for the seeding rate, t/ha & 1.98 & 0.42 & 0.21 \\
\hline $\begin{array}{l}\text { LSD } 05 \text { for the row-width spacing, } \\
\text { t/ha }\end{array}$ & & & 0.31 & \\
\hline
\end{tabular}

Thus, as a result of studying the influence of the Sudangrass cultivation technology elements on the Sudangrass yield of green mass, absolutely dry matter and seed productivity, it was found that Sudangrass variety Demskaia should be sown in the third decade of May with a seeding rate of 2.5 and $3.0 \mathrm{mln}$ fertile seeds per 1 ha. Sowing during this period provides higher productivity, while earlier or later sowing leads to a significant decrease in the yield and its quality. The best sowing method to produce seeds and fodder is continuous, ordinary row-sowing with a $15 \mathrm{~cm}$ row space. 
Sudangrass green mass exceeds many cereal crops in terms of nutritional value. The study established that the biochemical composition of the Sudangrass hay in the trials with different sowing times and seeding rates changed insignificantly (Tables 4 and 5). Depending on the sowing time, earlier sown treatments had the highest content of crude protein. In all the trials, the hay of the first mowing in the "early ear emergence - ear emergence" had $10.94-11.95 \%$ protein, $1.93-2.14 \%$ sugar, $52.28-54.51 \mathrm{mg} / \mathrm{kg}$ carotene per $1 \mathrm{~kg}$ of dry matter.

The conducted experiments demonstrated that the Sudangrass sowing rate has some effect on the nutrient content in plants. It was observed that the higher seeding rate increases the crude protein content increases in all trials from $10.28 \%$ with a seeding rate of $1.5 \mathrm{mln}$ fertile seeds per 1 ha up to $11.67 \%$ at $3.0 \mathrm{mln}$ fertile seeds per 1 ha.

There were no significant differences in the sugar content. According to the trials, the content of raw fibre in plants did not depend on the seeding rate: $35.51 \%$ at $1.5 \mathrm{mln}$ fertile seeds per 1 ha; $34.93 \%$ at $2.0 \mathrm{mln}$ fertile seeds per 1 ha and $35.51 \%$ at 3.0 million fertile seeds per 1 ha.

Table 4. The Sudangrass biochemical composition, depending on the sowing time at the rate of 2.5 $\mathrm{mln}$ seeds/ha, the 1st mowing, on average for 2017-2019 (\%based on the absolutely dry matter).

\begin{tabular}{|c|c|c|c|c|}
\hline Sowing time & Carotene mg/kg & Crude protein & Fiber & Sugar \\
\hline 1 & 52.75 & 11.95 & 35.20 & 2.01 \\
\hline 2 & 53.92 & 11.24 & 35.02 & 1.96 \\
\hline 3 & 54.30 & 10.94 & 35.46 & 2.02 \\
\hline 4 & 52.62 & 10.95 & 35.68 & 2.02 \\
\hline
\end{tabular}

Table 5. The effect of seeding rates on the Sudangrass biochemical composition when sown on May 27 , the 1st mowing, on average for 2017-2019 (\%based on the absolutely dry matter).

\begin{tabular}{|c|c|c|c|c|}
\hline Seeding rate & Carotene $\mathrm{mg} / \mathrm{kg}$ & Crude protein & Fibre & Sugar \\
\hline 1.5 & 52.94 & 10.28 & 35.51 & 2.00 \\
\hline 2.0 & 52.28 & 11.24 & 34.93 & 1.95 \\
\hline 2.5 & 52.85 & 11.54 & 35.42 & 2.14 \\
\hline 3.0 & 54.51 & 11.67 & 35.51 & 1.93 \\
\hline
\end{tabular}

The efficient use of light energy by Sudangrass to develop the green mass yield depends on many factors, including the leaf surface area, the growth rate, working time, the area of plant alimentation, photosynthetic potential, the net photosynthesis productivity and the conditions under which it takes place.

The conducted experiments showed that Sudangrass sown with a $15 \mathrm{~cm}$ row spacing had the largest leaf area. The higher row spacing width to $45 \mathrm{~cm}$ significantly decreases the leaf area (Table 6).

With the increased seeding rate from 1.5 to $3.0 \mathrm{mln}$ seeds/ha, there was a natural increase in the leaf surface area in all the sowing method trials.

Trials with a row spacing of $15 \mathrm{~cm}$ at the seeding rate of 2.5-3.0 mln fertile seeds per 1 ha had the highest photosynthetic potential (PP) during the growing period "full sprouts early ear emergence" $1.08-1.11 \mathrm{mln} \mathrm{m}^{2} /$ ha-days. When considering the interphase period "full shoots - full ripeness", the same trials developed the PP of 2.83-2.97 $\mathrm{mln} \mathrm{m}^{2} /$ ha-days.

It was revealed that the net photosynthesis productivity (NPP) decreases with the higher seeding rate and a corresponding increase in the leaf surface area. The NPP change with the changed sowing method was insignificant. 
Table 6. The impact of the sowing rates and methods on the main photosynthetic indicators of Sudangrass for the period "full sprouts-full ripeness", on average for 2017-2019.

\begin{tabular}{|c|c|c|c|c|}
\hline $\begin{array}{l}\text { Seeding rate, } \\
\mathrm{mln} \text { seeds/ha }\end{array}$ & $\begin{array}{c}\text { Row- } \\
\text { width } \\
\text { spacing, } \\
\mathrm{cm}\end{array}$ & $\begin{array}{c}\text { Leaf } \\
\text { area, } \\
\text { thsd } \mathrm{m}^{2} \\
\text { /ha }\end{array}$ & $\mathrm{PP}, \mathrm{mln} \mathrm{m}^{2} /$ ha-days & $\begin{array}{l}\text { NPP, gr }{ }^{/ m 2} \text { per } \\
\text { day. }\end{array}$ \\
\hline 1.5 & \multirow{4}{*}{15} & 22.03 & 1.88 & 8.2 \\
\hline 2.0 & & 28.02 & 2.37 & 7.1 \\
\hline 2.5 & & 33.17 & 2.83 & 6.9 \\
\hline 3.0 & & 34.77 & 2.97 & 6.8 \\
\hline 1.5 & \multirow{4}{*}{30} & 20.50 & 1.75 & 7.8 \\
\hline 2.0 & & 24.20 & 2.07 & 7.8 \\
\hline 2.5 & & 24.73 & 2.11 & 7.5 \\
\hline 3.0 & & 26.37 & 2.25 & 7.1 \\
\hline 1.5 & \multirow{4}{*}{45} & 15.92 & 1.36 & 8.4 \\
\hline 2.0 & & 20.36 & 1.74 & 7.1 \\
\hline 2.5 & & 22.73 & 1.94 & 7.0 \\
\hline 3.0 & & 22.75 & 1.94 & 7.1 \\
\hline
\end{tabular}

An essential indicator of the photosynthetic activity of plants, including Sudangrass, is the leaf surface growth dynamics (Table 7). The analysis of the trials with Sudangrass sown at different seeding rates and methods distinguished roughly three periods.

The first period is from the beginning of germination to the end of tubulation. This period is characterized by the slow development of the leaf surface and, accordingly, the effect of sowing methods and rates is imperceptible.

The second period is from the beginning to full ear emergence. The period is characterized by the most intensive growth of the leaf area. There are significant differences in the growth of the leaf area between the trials. It is higher in plants sown with a row spacing of $15 \mathrm{~cm}$ than wider rows. The treatments with the seeding rate of 2.5-3.0 mln fertile seeds per 1 ha reach the largest leaf area much faster.

In the third period, which begins from the flowering phase, there is a gradual decrease in the leaf area due to their decline. The "full ripeness" phase is characterized by the reduced leaf area on average to 11.1 thousand $\mathrm{m}^{2} /$ ha, i.e. by three times.

Table 7. The growth of the leaf surface area at different seeding rates and sowing methods in 2017-2018 (thsd $\mathrm{m}^{2} / \mathrm{ha}$ ).

\begin{tabular}{|c|c|c|c|c|c|c|c|}
\hline \multirow{2}{*}{$\begin{array}{c}\text { Seeding rate, } \\
\mathrm{mln} \\
\mathrm{pcs} / \mathrm{ha}\end{array}$} & \multirow{2}{*}{$\begin{array}{l}\text { Row-width } \\
\text { spacing } \\
\mathrm{cm}\end{array}$} & \multicolumn{2}{|c|}{ the 1 st period } & \multicolumn{2}{|c|}{ the 2 nd period } & \multicolumn{2}{|c|}{ the 3 rd period } \\
\hline & & $6 / 06$ & $26 / 06$ & $5 / 07$ & $14 / 07$ & $2 / 08$ & $31 / 08$ \\
\hline 1.5 & \multirow{4}{*}{15} & 3.9 & 28.0 & 29.7 & 39.2 & 21.3 & 12.4 \\
\hline 2.0 & & 4.5 & 25.0 & 34.4 & 35.9 & 24.3 & 14.0 \\
\hline 2.5 & & 5.7 & 28.9 & 41.7 & 46.9 & 30.6 & 16.1 \\
\hline 3.0 & & 6.9 & 28.8 & 45.4 & 46.4 & 25.8 & 17.2 \\
\hline 1.5 & & 3.0 & 16.8 & 25.8 & 26.4 & 18.7 & 8.7 \\
\hline 2.0 & & 3.7 & 18.4 & 28.4 & 30.1 & 18.5 & 10.5 \\
\hline
\end{tabular}




\begin{tabular}{|c|c|c|c|c|c|c|c|}
\hline 2.5 & \multirow[t]{2}{*}{30} & 4.0 & 22.7 & 28.0 & 32.1 & 20.0 & 9.2 \\
\hline 3.0 & & 4.4 & 20.0 & 29.2 & 34.0 & 15.7 & 10.2 \\
\hline 1.5 & \multirow{4}{*}{45} & 1.8 & 13.7 & 19.3 & 20.2 & 8.9 & 6.6 \\
\hline 2.0 & & 2.8 & 15.0 & 23.5 & 28.1 & 14.3 & 8.7 \\
\hline 2.5 & & 3.3 & 21.2 & 26.4 & 37.3 & 15.6 & 10.4 \\
\hline 3.0 & & 3.5 & 18.1 & 31.1 & 30.7 & 17.0 & 9.8 \\
\hline
\end{tabular}

\section{Conclusion}

Thus, the present research found that in the conditions of the Cis-Ural steppe of the Bashkortostan Republic, the Sudangrass variety Demskaia develops the highest productivity of green mass and seeds when sowing with a seeding rate of 2.5-3.0 mln fertile seeds per 1 ha in rows (the row spacing of $15 \mathrm{~cm}$ ). The best sowing time for Sudangrass when the studied variety develops the highest fodder weight is the end of the third decade of May when the soil will steadily warm up to $+14^{\circ}-+18^{\circ} \mathrm{C}$ and cold weather is unlikely to return. It was revealed that earlier sown trials with a seeding rate of 2.5-3.0 mln fertile seeds per 1 ha had the highest crude protein content. An increase in the seeding rate from 1.5 to $3.0 \mathrm{mln}$ fertile seeds per 1 ha leads to an increase in the leaf surface area, their photosynthetic potential and a decrease in the net photosynthesis productivity in the studied variants.

The Sudangrass leaf surface area reaches its maximum (46.9 thsd $\mathrm{m}^{2} / \mathrm{ha}$ ) at the "full ear emergence" phase when the crop is sown with a seeding rate of 2.5-3.0 mln fertile seeds per 1 ha, a row spacing of $15 \mathrm{~cm}$.

\section{Acknowledgements}

The study was carried out in the Seed-Breeding Center for Forage Crops of UFRC RAS" (project No. 075-15-2021-549).

\section{References}

1. S.V. Kadyrov, Sorghum in the Central Chernozem regions, 80 (Rostov-on-don, 2008)

2. N.I. Kashevarov, R.I. Polyudina, N.V. Balykina, A.P. Shtaus, Sudan grass in forage production in Siberia, 224 (Novosibirsk, 2004)

3. Yu.K. Novoselov, G.D. Kharkiv, N.S. Shekhovtsova, Methodological guidelines for conducting field experiments with forage crops, 198 (operational printing Division of the VIC, Moscow, 1983)

4. N.A. Kovtunova, Achievements of Science and Technology of AIC 6 (30), 4851(2016)

5. B.A. Dospekhov, Methodology of a field trial (with the basis of statistic processing of study results), 351 (Alyans, Moscow, 2014)

6. State methodology for crop variety testing, 250 (Moscow, 1989)

7. R.A. Biktimirov, Z.M. Sharipkulova, I.O. Chanyshev, A.Kh. Shakirzyanov, Kh.M. Safin, I.P. Leont'yev, Modern cultivation technology of Sudan grass in the Republic of Bashkortostan, 58 (Mir pechati, Ufa, 2019) 
8. R.A. Biktimirov, A.Kh. Shakirzyanov, A.A. Nizaeva, Achievements of Science and Technology of AIC 8 (33), 46-49 (2019) 